\title{
WILSON'S DISEASE
}

\section{A case report and a historical review}

\author{
Egberto Reis Barbosa', Alexandre Aluízio Costa Machado', \\ Eduardo Luiz Rachid Cançado ${ }^{2}$, Marta Mitiko Deguti', Milberto Scaff'
}

\begin{abstract}
The purpose of this report is to present a short review of the history of Wilson's disease and to describe the first diagnosed case at the Neurologic Clinic of Hospital das Clinicas of São Paulo University Medical School. The topics of the historical review are the first contributions of authors along the second half of the XIX century, the seminal monograph of Samuel Alexander Kinnier Wilson (1912), the landmarks in the investigation of mechanisms of the disease and the introduction of the first effective treatment by John Walshe (1956). The first case studied in our Clinic, in 1946, was a 20 year-old male whose main neurological manifestations were postural tremor ("wing beat") and dysarthria and could be characterized as WestphalStrümpell form of the disease. Along the discussion of this case difficulties to establish the diagnosis and to treat the patient at that time are highlighted. We conclude with a brief history of the development of researches on Wilson's disease in our Clinic, with an honor to the pioneer contributions of Horacio Martins Canelas.
\end{abstract}

KEY WORDS: Wilson's disease, historical review, copper metabolism.

\section{Doença de Wilson: relato de caso e revisão histórica}

Resumo - Neste artigo inicialmente é feito um retrospecto dos principais marcos na história dos conhecimentos sobre a doença de Wilson, desde as primeiras descrições de casos no século XIX, passando pela magnífica monografia de Samuel Alexander Kinnier Wilson, m 1912, pelas descobertas sobre a causa da doença e chegando à era do tratamento efetivo da moléstia inaugurada por Walshe em 1956. A seguir, relata-se o primeiro caso de doença de Wilson estudado na Clínica Neurológica do HC-FMUSP. O paciente admitido na Clínica Neurológica em 1946, aos 20 anos de idade, apresentava a variante da doença em que predominavam tremor postural e disartria, conhecida como forma de Westphal-Strümpell. Na discussão, são ressaltadas as dificuldades da época para a confirmação do diagnóstico e para o tratamento; além de se realizar um breve histórico do estudo da doença na Clínica Neurológica, com o devido realce para a figura de Horácio Martins Canelas, pela sua participação pioneira nas pesquisas sobre a doença de Wilson em nosso meio.

PALAVRAS-CHAVE: doença de Wilson, revisão histórica, metabolismo do cobre.

Wilson's disease (WD) is an autosomal recessive disorder of the copper metabolism leading to the accumulation of this metal in different organs and tissues. Hepatic and neurological symptoms are the main clinical features of the disease.

Some authors ${ }^{1-3}$ attribute to FT Frerichs the first case report of WD, in 1861. The patient described by Frerichs was a 9-year-old boy who developed neurological symptoms characterized at the beginning by speech changes and difficulty to control the movements of the limbs. He later developed intention tremor, difficulty in swallowing and died at the age of 10 . The autopsy revealed abnormalities compatible with cirrhosis of the liver².
Westphall ${ }^{4}$, in 1883, reported the study of two cases which had as the main neurological manifestation a tremor similar to that seen in patients with multiple sclerosis but their necropsy did not show the typical white matter lesions of this disease, well-known at that time. For this reason, Westphall used the term "pseudosclerosis" for this new disease.

Strümpell ${ }^{5,6}$ reported in 1898 and in 1899, three other cases of pseudosclerosis and the pathology of the third one revealed the presence of cirrhosis of the liver.

Gowers (apud Tyler ${ }^{7}$ ), in 1888, described the cases of a 10 year-old boy and his sister, in which there were a predominance on the clinical picture of a kind of move-

Department of Neurology ${ }^{1}$ and Department of Gastroenterology ${ }^{2}$ of São Paulo University Medical School, São Paulo SP, Brazil.

Received 25 September 2008, received in final form 5 January 2009. Accepted 28 March 2009.

Dr. Egberto Reis Barbosa - Rua Sergipe 401 / 311 -01243-001 São Paulo SP - Brasil. E-mail: egbertob@8415.com.br 
ment disorder that was named by the author as "tetanoid chorea".

In 1906, Gowers (apud Wilson'), in his new report named "On tetanoid chorea and its association with cirrhosis of the liver" described with more details the neurological abnormalities seen in one of the patients as: "both arms presented slow changing tonic spasm... at times the spasm changed so that the fingers were spasmodically extended; occasionally they were spread out and moved irregularly in a manner resembling athetosis". This description shows clearly that Gowers referred to what today is called dystonic movements and postures. Illustrating this report there is a photo of the patient where we can see the dystonic postures of the four members ${ }^{7}$. The pathological findings of both cases revealed the presence of cirrhosis of the liver while there were no defined lesions in the brain.

$\mathrm{Ormerod}^{8}$, in 1890, reported a similar case in a 10 year-old child with rapid-onset of neurological manifestations along 3 to 4 months and he described them like this: "weakness of right hand and arm, with cramped position of the fingers, soon followed by difficulty of speech. Drawing of the face, then an unnatural gait. Speech gets worse; he seems silly; has some difficulty in swallowing. Gait much worse. Lastly some affection of left arm and hand". The progression was fast and the death came 8 months after the beginning of the symptoms. In this seminal report, we can identify some neurological features that are hallmarks of the disease: the presence of a motor disorder affecting at the beginning, the right hand and arm suggesting dystonia; the early and severe involvement of speech; the facial expression compatible with risus sardonicus; and the quick progression to death in less than a year, as it can occur in the dystonic form of WD. The necropsy showed necrosis of the external segment of the lentiform nucleus (putamen) and the presence of cirrhosis of the liver. These pathological findings are in agreement with the diagnosis of Wilson's disease. In this remarkable report, Ormerod emphasized the great similarity between his case and those reported by Gowers two years before with the patients described by Homén 9 in the same year (1890). Homén's report included 3 siblings (two males and a female) with ages at the onset of the disease ranging from 12 to 21 years old, and neurological manifestations similar to those described by Ormerod, although with a slower progression. Severe damage of nucleus lentiform and cirrhosis of the liver were also observed by Homén in his cases, despite he thought these were related to syphilis.

In 1902, Kayser $^{10}$ reported the presence of a greenishbrown ring around the cornea of a 23-year-old man, thought to have multiple sclerosis. In the following year, Fleisch$\mathrm{er}^{11}$ (1903) described the same pigmented ring in a case of "pseudosclerosis" and in another case of multiple sclerosis.
In 1911, Wilson ${ }^{1}$ presented his monograph describing the "progressive lenticular degeneration" that resulted in the publication of a historical paper in Brain"journal, in 1912, with the title"Progressive lenticular degeneration: a familial nervous disease associated with cirrhosis of the liver. Briefly versions of the same study were published in 1912, in two other journals: the "Lancet" and the "Revue Neurologique" (Paris). In these seminal reports Wilson described four personal cases (three of them with neuropathological study), two referred (but not studied) by Gowers and Ormerod and six other cases from the literature (the cases described by Gowers; Ormerod and Homén). He emphasized the familial character of some cases and the presence of cirrhosis of the liver, mostly asymptomatic, but claimed that the liver did not contribute to the clinical progression of the disease. Bramwell, in 1916, was the first to realize the importance of liver pathology in WD, when he described a family in which 4 siblings died of "acute fatal cirrhosis" all between 9 and 16 years of age, and suggested that this cases might have been related to those reported by Wilson 4 years before ${ }^{12}$.

Wilson did not see at his first papers a relationship between his cases and the pseudosclerosis of WestphalStrümpell. However, two years later, while writing on "progressive lenticular degeneration", Wilson mentioned similarities between the two entities ${ }^{13}$.

In 1920, Spielmeyer ${ }^{14}$, contesting the ideas of Von Hoesllin and Alzheimer ${ }^{15}$ concluded that, from the neuropathological point of view, pseudosclerosis and WD were the same disease.

The controversy between the followers of Wilson's ideas about the unity of the two entities and Westphal, Strümpell and Alzheimer's school, who considered them as independent, was definitely over in 1921 with the publication of Hall's monograph ${ }^{13}$. This author, based on the review of 64 cases of literature and studies of four personal cases, demonstrated in a conclusive way the identity between the two diseases. Furthermore Hall pointed out their inheritable character and assembled the two diseases under the name of "hepatolenticular degeneration".

Once established the clinical characterization of the disease, the studies started to be orientated toward its ethiopathogenesis.

Rumpel $^{16}$, in 1913, had already mentioned by the first time the increase of the amount of copper in the liver of a patient with pseudosclerosis.

According to Scheinberg and Sternlieb ${ }^{3}$, Vogt, in 1929, Haurowitz, in 1930, and Glazebrook, in 1945, demonstrated the accumulation of copper in the liver and in the basal ganglia of patients with WD.

In 1948, some important discoveries brought a great advance to elucidation of metabolic disorders of WD. In this year Mandelbrote et al. ${ }^{17}$ studying the copper me- 
tabolism in multiple sclerosis noticed that in the control group, that included patients with other neurological diseases, one patient with Wilson's disease presented an increase of urinary excretion of copper. In a two-hour period the patient with WD excreted $41.7 \mu \mathrm{g}$ of copper, whereas none of the other twelve patients studied excreted more than $18 \mu \mathrm{g}$. In the same year Cumings ${ }^{18}$ definitely proved the accumulation of copper in the liver and in the brain of patients with WD.

Along the 1950's the investigation on WD concentrated on the study of the copper metabolism and on the treatment of the disease aiming to reduce copper accumulation. In 1952, Scheinberg and Gitlin ${ }^{19}$ demonstrated the decreased level of ceruloplasmin in patients with WD and, in 1954, Cartwright et al. ${ }^{20}$ reported the increase of serum free copper, not bound to ceruloplasmin, in patients with WD.

The attempts of treatment with copper chelating agents were unsuccessful until the introduction of the penicillamine by Walshe ${ }^{21}$, in 1956, what made possible the long term treatment of the disease, so far always fatal. The efficacy of penicillamine in the treatment of WD was recognized only after several years. To illustrate this fact in the book published by Boudin and Pepin ${ }^{22}$ on WD, in 1959, this drug was put in the same plane of others therapeutic options that later revealed completely ineffective such as isoniazide and sodium thiomalate.

From 1946 to 1961, six cases of the WD were evaluated in the Neurologic Clinic of the Hospital das Clínicas of São Paulo University Medical School (HC-FMUSP). The first of these cases, evaluated in 1946, is the objective of this report.

\section{CASE}

A 20-year-old white male, was admitted to the Neurologic Clinic in March 29 $9^{\text {th }}, 1946$ under the care of Drs Ibrahim Mathias and Oswaldo Lange (Fig 1). He had an 18-month history of tremors. At the beginning, he noticed tremor in his right arm when holding a cup or a glass. After 2 months, the tremor became continuous and extended to the left arm, head and legs. He also noticed speech changes with the disease progression. The tremor kept occurring, now at rest, making it difficult for the patient to perform all motor activities, leaving him bedridden at last. At this time, he was admitted to the Neurologic Clinic.

The ophthalmologic evaluation showed the presence of the Kayser-Fleischer's ring (Fig 2). On physical examination the main findings were: jaundice, enlargement of the liver, splenomegaly and the presence of abdominal collateral circulation.

The neurological examination disclosed an intense tremor involving the four limbs, specially the right side, and the head (on Fig 3, it is possible to notice the image of the tremor in the upper limbs). It was of wide amplitude, present at rest, and would get worse during voluntary movements. Hypotonia of the upper limbs was also present. The orthostatic position was only possible with a wide base, a feature maintained during gait. He also had dysarthria with scanned speech. The tremors interfered with the motor evaluation, specially in the tests for cerebellar function such as the index-nose and alternating movements of the hands to check for dysdiadochokinesia. Deep-tendon reflexes were normal and the plantar reflexes were flexor. The facial expression was described in this way: "the patient has a face of almost constant smile and his lips remain in the assumed posture in opposition to the rest of his facial mimic". From this description, it is possible to deduce that the patient presented the risus sardonicus, as it can be seen in Fig 4.

The patient was submitted to a pneumoencephalograph that showed "ex-vacuo" enlargement of the third ventricle and lateral ventricles. The therapeutic measures adopted just to relief the symptoms were: low fat diet, scopolamine and phenobarbital. Along the course of the disease, he presented aggressive behavior which became progressively more intense and required his transfer to a psychiatric hospital (Hospital do Juquery), where he died five years after the onset of the disease.

\section{DISCUSSION}

We present in this report, the first case of WD seen at the Neurologic Clinic of Hospital das Clínicas of São Paulo University Medical School (HC-FMUSP), in 1946.

The patient presented the Westphal-Strümpell's form of the disease, with onset in third decade of life and neurological manifestations dominated by postural tremor. The authors describe the tremor as being of great amplitude, especially in posture and during movement, and the photo observation, where the image shows clearly the movement of the upper limbs, demonstrate that the hyperkinesia represents the typical postural tremor of WD, called "wing beat" tremor.

At that time, the diagnosis of WD was based only on the neurologic and hepatic features as well as the presence of the Kayser-Fleischer's ring, since the copper metabolism disorders and the reduction of ceruloplasmin level were not known. It was twelve years later, in 1948, that Cumings ${ }^{18}$ described the copper abnormalities in WD and posteriorly, in 1952, Scheinberg and Gitlin ${ }^{19}$ showed that the ceruloplasmin levels were low in most of WD patients.

The pneumoencephalograph images were compatible with subcortical atrophy, as it was expected in patients with WD.

The treatment is this case was palliative as at that time there was no specific therapy available. The therapeutic strategies adopted included: low fat diet, recommended in face of the evident hepatic involvement, scopolamine as an attempt to control the tremor and phenobarbital as a sedative. The disease, as expected, followed its natural course and the patient died 5 years after the onset of his first symptoms. It's important to emphasize that in Westphal-Strümpell form of the disease, as presented by this patient, the duration of the disease until death is longer 
than that seen in Wilson's form in which prevail dystonic manifestations. In patients affected by Wilson's form of the disease the evolution is faster and the natural course of the disease frequently lasts less than 3 years.

The first treatment attempts with the chelating agent dimercaprol (British Anti-Lewisite-BAL) were done in 1951 by two independent groups: Cumings ${ }^{23}$ in England and Denny-Brown and Porter ${ }^{24}$ in the USA, with little improvement of disease symptoms. In 1956, as it was mentioned before, Walshe ${ }^{20}$ introduced penicillamine that revolutionized WD treatment.

In conclusion, this historical report demonstrates that WD diagnosis is mostly based on the clinical features of the disease and for its confirmation, even today, the neurological manifestations and the presence of the KayserFleischer's ring practically make the diagnosis. The crucial difference between that time and nowadays is the current availability of effective treatment options.

The Brazilian neurological literature registers one WD case report before this one, made by Austragésilo Filho ${ }^{25}$ in 1944. The author described the patient main neurological manifestation as torsion spasms (possibly dystonic movements) suggesting a dystonic form of WD. In this report the author did not mention the presence of KayserFleicher's ring but the age of disease onset (18 years of age), the progression to death after 4 years and the hepatic cirrhosis and brain abnormalities found at the necropsy indicated that the patient indeed had WD.

As mentioned earlier, after this first case of WD recorded in our Clinic, other 5 were evaluated later along the 1950's. In all of them, the progression was always fatal despite any treatment attempts with the copper chelating BAL, already available in several countries since its introduction as a rational treatment for WD, in 1951.

In the beginning of the 1960's, penicillamine had already been used in several countries in Europe and in the USA and its efficacy was definitively proved. Thus WD had left a long list of untreatable inherited metabolic neurological diseases and had begun to attract the interest of a growing number of researchers all around the world, worried about the precise diagnosis and the correct treatment. At that time, in our country, Horacio Martins Canelas developed a project to investigate WD which would become in the following decades one of the most profitable lines of research at the Neurologic Clinic (HCFMUSP). To develop this research project, Canelas had the collaboration of Francisco Bastos De Jorge that would cooperate with the laboratorial support, essential for the study of the disease.

In this way, in 1962, Canelas published, with De Jorge and Costa-Silva's collaboration a paper focusing copper determination methodology in biological materials ${ }^{26}$. In the following year, Canelas published with De Jorge and
Spina-França's participation, a study concerning normal values of copper in blood, cerebrospinal fluid and urine ${ }^{27}$. In 1964, again with De Jorge's collaboration, a study of ceruloplasmin levels in normal individuals was published by Canelas ${ }^{28}$. In the same year, Canelas and his collaborators achieved an international publication in Clinica Chimica Acta (Amsterdam, Holland) concerning copper concentration in saliva, salivary glands and pancreas ${ }^{29}$. With these studies, pioneers in our country, Canelas and his team achieved the know-how of laboratorial tools to evaluate copper metabolism.

Besides the investigations in the laboratorial domain Canelas and his team reported important clinical studies. Thus, in 1963, Canelas and his collaborators published a detailed study of 3 cases of WD, two of them with neuropathological examination ${ }^{30}$. In 1967, Canelas and his collaborators published in the Journal of Neurology, Neurosurgery and Psychiatry an interesting comparative study of copper metabolism in patients with WD undergoing a vegetarian and mixed $\operatorname{diet}^{31}$. With these publications, Canelas put the Neurologic Clinic (HC/FMUSP) as a national reference Center for WD research.

This line of investigation is up to nowadays one of the most traditional of the Neurologic Clinic (HC-FMUSP) and for the last 20 years, has counted with an effective participation of researchers from the Gastroenterology Department ${ }^{32-34}$.

\section{REFERENCES}

1. Wilson SAK. Progressive lenticular degeneration: a familial nervous disease associated with cirrhosis of the liver. Brain 1912;34:295-509.

2. Owen CA. Wilson's disease: the etiology, clinical aspects, and treatment of inherited copper toxicosis. New Jersey: Neyes, 1981:1-22.

3. Scheinberg H, Sternlieb. Wilson's disease. Philadelphia: Saunders, 1984:4-8.

4. Westphal C. Über eine dem Bilde der cerebrospinalen grauen Degeneration ähnliche Erkrankung des centralen Nervensystems ohne anatomische Befund nebst einigen Bemerkungen über paradoxe Contraction. Arch Psychiat Nervenkrh 1883;14:87-134.

5. Strümpell A. Über die Westphal'sche Pseudosklerose und über diffuse Hirnsklerose, insbesondere bei Kindern. Dt Z Nervheilk 1898;12:116-149.

6. Strümpell A. Ein weiterer Beitrag zur Kenntniss der sog. Pseudosklerose. Dt Z Nervheilk 1899;14:348-355.

7. Tyler K. Fragments of neurologic history: "Tetanoid chorea" and progressive lenticular degeneration. Neurology 1983; 33:461-463.

8. Ormerod JA. Cirrhosis of the liver in a boy, with obscure and fatal nervous symptoms. St Bartholomew's Hosp Rep 1890;26:56-68. 
9. Homén EA. Eine eigenthümliche Familienkrankheit, unter den form einer progressiven Dementia, mit besbesonderem anatomischen Befund. Neurol Zentralblat 1890;9:514-518.

10. Kayser B. Ueber einen Fall von angeborener grünlicher Verfärfung der Cornea. Klin Mbl Augenheilk 1902;40:22-25.

11. Fleischer B. Zwei weitere Fälle von grünlicher Verfärbung der Kornea. Klin Mbl Augenheilk 1903;41:489-491.

12. Walshe JM. History of Wilson's disease: 1912-2000. Mov Disord 2006;21:142-147.

13. Hall HC.La Dégénérescence hépato-lenticulaire. Paris, Masson, 1921.

14. Spielmeyer W. Die histopathologische Zuzammengehörigkeit der Wilsonschen Krank heit und der Pseudosklerose. Z Ges Neurol Psychiat 1920;57:312-351.

15. von Hoesllin C, Alzheimer A. Ein Beitrag zur Klinnik und pathologischen Anatomie der Westphal-Strumpellschen Pseudosklerose. Z Ges Neurol Psychiat 1912;8:183-209.

16. Rumpel A. Über das Wesen und die Bedeutung. der Leberveränderungen und der Pigmentierungen bei den damit verbunden Fällen von Pseudosklerose, zugleich ein Beitrag zur Lehre von der Pseudosklerose (Westphal-Strümpell). Dtsch Z Nervenkeilk 1913;49:54-73.

17. Mandelbrote BM, Stanier MW, Thompson RHS, et al. Studies on copper metabolism in demyelinating diseases of the central nervous system. Brain 1948;71:212-228.

18. Cumings JN. The copper and iron of brain and liver in the normal and in hepatolenticular degeneration. Brain 1948;71:410-415.

19. Scheinberg IH, Gitlin D. Deficiency of ceruloplasmin in patients with hepatolenticular degeneration (Wilson's disease). Science 1952;116:484-485.

20. Cartwright GE, Hodges RE, Gubler CJ, et al. Studies on copper metabolism. XIII: Hepatolenticular degeneration. J Clin Invest 1954;33:1487-1501.

21. Walshe JM. Wilson's disease: new oral therapy. Lancet 1956;i: 25-26.

22. Boudin G Pepin B. Dégénérescence Hépato-Lenticulaire. Masson, Paris, 1959 :75-87.
23. Cumings JN. The effects of BAL in hepatolenticular degeneration. Brain 1951;74:10-22.

24. Denny-Brown D, Porter H. The effect of BAL (2,3-dimercaptocapropanol) on hepatolenticular degeneration (Wilson's disease). N Engl J Med 1951;245:917-925.

25. Autragésilo Filho A. Degeneração mucóide da oligodendroglia em um caso de enfermidade do tipo Wilson. Arq Neuropsiquiatr 1944;2:170-176.

26. Canelas HM, De Jorge FB, Costa-Silva. Contribuição ao estudo do metabolismo do cobre.I: Metodologia da determinação do cobre em materiais biológicos. Rev Paul Med 1962;61:350355.

27. Canelas HM, De Jorge FB, Spina-França A. Contribuição ao estudo do metabolismo do cobre. II: Valores normais do cobre no sangue, líquido cefalorraqueano e urina. Rev Paul Med 1963;62:125-128.

28. Canelas HM, De Jorge FB. Contribuição ao estudo da ceruloplasmina. I: Valores normais no soro sangüíneo. Arq Neuropsiquiatr 1964;22:271-276.

29. Canelas HM, De Jorge FB, Dias JC, Cury L. Studies on cooper metabolism. III: Cooper contents of saliva, pancreas, and salivary glands. Clin Chim Acta (Amsterdam) 1964;9:148-150.

30. Canelas HM, De Jorge FB, Escalante OD, et al. Hepatolenticular degeneration: clinical and biochemical study. Arq Neuropsiquiatr 1963;21:229-250.

31. Canelas HM, De Jorge FB, Tognola WA. Metabolic balances of cooper in patients submitted to vegetarian and mixed diets. J Neurol Neurosurg Psychiat 1967;30:371-373.

32. Cançado ELR, Rocha MS, Barbosa ER, et al. Ultra-sonografia abdominal na degeneração hepatolenticular: estudo de 33 casos. Arq Neuropsiquiatr 1987;45:131-136.

33. Deguti M, Genschel J, Cançado ER, et al. Wilson disease: novel mutations in the ATP7B gene and clinical correlation in brazilian patients. Hum Mut 2004;23:398-406.

34. Neurological manifestations in Wilson's disease: report of 119 cases. Machado AAC, Barbosa ER, Chien HF, et al. Mov Disord 2006;12: 2192-2196. 